\title{
Investigation of the relationship of substance use disorders with hopelessness, anxiety sen- sitivity, impulsivity and sensation seeking per- sonality traits in adolescents
}

Ergenlerde madde kullanım bozukluklarının umutsuzluk, anksiyete duyarlılı̆̆ı, dürtüsellik ve heyecan arama kişilik özellikleri ile ilişkisinin incelenmesi

Sabide Duygu Uygun1, Esra Çöp², Kadir Özdel33, Mustafa Tunçtürk4, Arzu Çiftçi5, Gül Karaçetin4, Özden Şükran Üneri6

${ }^{1}$ M.D., University of Health Sciences, Dr. Sami Ulus Maternity, Children's Health and Diseases Training and Research Hospital, Department of Child and Adolescent Psychiatry, Ankara, Turkey https://orcid.org/0000-0003-1177-7256

2 M.D., University of Health Sciences, Ankara Child Health and Diseases Hematology Oncology Training and Research Hospital, Department of Child and Adolescent Psychiatry, Ankara, Turkey https://orcid.org/0000-0001-8451-0099

${ }^{3}$ Assoc. Prof., University of Health Sciences, Ankara Diskapi Yildirim Beyazit Training and Research Hospital, Department of Psychiatry, Ankara, Turkey https://orcid.org/0000-0002-3712-9444

4 M.D., University of Health Sciences, Bakirkoy Prof. Dr. Mazhar Osman Training and Research Hospital, Department of Child and Adolescent Psychiatry, Istanbul, Turkey https://orcid.org/0000-0003-3928-3194-https://orcid.org/0000-0002-9109-6559

5 M.D., University of Health Sciences, Bakirkoy Prof. Dr. Mazhar Osman Training and Research Hospital, Child and Adolescent Alcohol and Drug Research Treatment and Training Center, Istanbul, Turkey https://orcid.org/0000-0002-0431-9807

6 Prof., Yildirim Beyazit University, Ankara Child Health and Diseases Hematology Oncology Training And Research Hospital, Department of Child and Adolescent Psychiatry, Ankara, Turkey https://orcid.org/0000-0002-7869-5338

SUMMARY

Objective: In addition to the relationship between substance use and personality, the personality traits such as hopelessness, anxiety sensitivity, impulsivity, and sensation seeking are known to be particularly predictive of later substance misuse. These personality traits can be used as markers to provide early prevention intervention against substance use disorders. The present study aims to evaluate the relationship of the personality traits to substance use disorders (SUDs). Method: The sample for the first analysis consisted of 13-18-year-old outpatients with SUDs $(n=30)$, outpatients with any psychiatric disorders other than SUDs $(n=30)$, and community-based non-matched healthy controls $(n=30)$. And then, the analysis for comparison among SUDs patient group and another healthy control group matched for age and sex $(n=30)$ was repeated to minimize bias because of the gender heterogeneity in the groups. Substance abuserelated personality traits were measured with the Substance Use Risk Profile Scale (SURPS). Also, Beck Hopelessness Scale, the State-Trait Anxiety Inventory, Barratt Impulsivity Scale and Arnett Inventory of Sensation Seeking were used as data collection tools. Using independent samples t-test or one-way ANOVA and Tukey posthoc tests among two or more groups, the relationship was evaluated. Results: Results show that there is no clear relationship between substance use disorders, and substance abuse-related personality traits measured by SURPS, with significant limitations. Discussion: Our study is the first study assessing this relationship in a sample of Turkish adolescents. Further studies should be planned to determine whether the result of our study reflects objective reality or is affected by the limitations.

Key Words: Adolescent, substance use disorders, personality traits
Amaç: Madde kullanımı ile kişilik arasındaki ilişkiye ek olarak, umutsuzluk, anksiyete duyarlılığı, dürtüsellik ve heyecan arama kişilik özelliklerinin özellikle daha sonraki madde kötüye kullanımının yordayıcısı olduğu bilinmektedir. Bu kişilik özellikleri, madde kullanım bozukluklarını önlemeye yönelik erken müdahaleler sağlamak amacıyla belirteçler olarak kullanılabilir. Bu çalışmanın amacı, bu özelliklerin madde kullanım bozuklukları (MKB) ile ilişkisini değerlendirmektir. Yöntem: İlk analizde örneklem 13-18 yaş arası MKB olan ayaktan hasta grubundan $(n=30), M K B$ dışında herhangi bir psikiyatrik bozukluğu olan ayaktan hasta grubundan $(n=30)$ ve toplum temelli eşleştirilmemiş sağlıklı kontrol grubundan $(n=30)$ oluşmaktaydı. Sonra, gruplardaki heterojen cinsiyet dağılımı nedeniyle yanlılığı en aza indirmek için MKB olan hasta grubu ile yaş ve cinsiyet olarak eşleştirilmiş başka bir sağlıkı kontrol grubunun $(n=30)$ karşılaştırılması amacıyla analiz tekrarlandı. Madde bağımlılığı ile ilişkili kişilik özellikleri Madde Kullanımı Risk Profili Ölçeği (MKRPÖ) ile değerlendirildi. Ayrıca, veri toplama araçları olarak Beck Umutsuzluk Ölçeği, Durumluk Sürekli Kaygı Envanteri, Barratt Dürtüsellik Ölçeği ve Arnett Heyecan Arama Ölçeği kullanıldı. Bulgular: Sonuçlar, MKRPÖ ile değerlendirilen madde kötüye kullanımı ile ilişkili kişilik özellikleri ve madde kullanım bozuklukları arasında önemli kısıtlılıklar ile birlikte net bir ilişki olmadığını göstermektedir. Sonuç: Çalışmamız, Türk ergenlerinden oluşan bir örneklemde bu ilişkiyi değerlendiren ilk çalışmadır. Çalışmamızın sonucunun nesnel gerçekliği yansıtıp yansıtmadığını ya da kısıtlılıklardan etkilenip etkilenmediğini belirlemeye yönelik ileri çalışmalar planlanmalıdır.

Anahtar Sözcükler: Ergen, madde kullanım bozuklukları, kişilik özellikleri 


\section{INTRODUCTION}

At present, substance use disorder (SUD) is considered as a global public health problem (1). Substance use in adolescence has been increased in the last 25 years (2). Due to the continuing biological, psychological and social development during adolescence, substance use in this period causes a range of consequences, including the development of mental health disorders, poor school performance, drop out of school, inability to have any occupation, loss of money, relationship problems, risky sexual behaviors, violence and criminal problems (3). Early-onset of substance use is a major risk factor for SUDs that affect economies, families and individuals' lives. Therefore, effective prevention to reduce adolescent substance use is important, and the risk factors of substance use should be identified in adolescence (4).

Substance use is associated with personality (5), and the personality traits such as hopelessness, anxiety sensitivity, impulsivity, and sensation seeking are known to be particularly predictive of later substance misuse $(6,7)$. Woicik et al. (8) focused on the importance of these specific personality profiles in drug abuse vulnerability, and developed the Substance Use Risk Profile Scale (SURPS) measuring these traits to evaluate the risk of substance use. The relationship between these personality traits and the substance abuse is mediated by different motivations (8). Individuals with high levels of internalizing profiles (anxiety sensitivity and hopelessness) were discussed to be more susceptible to the negative reinforcement motives of substance use as coping with anxiety and the panic symptoms and self-medication to relieve negative affective states (9). Moreover, individuals with the high levels of externalizing profiles (sensation seeking and impulsivity) were considered to be more susceptible to the positive reinforcement motives of substance use as intense novelty desire and poor behavioral inhibition to enhance positive affective states $(10,11)$.

In accordance with these previous studies, the four high-risk personality traits that were indicated to be related to substance use can be used as markers to provide early prevention intervention against subs- tance use disorders. Therefore, our study was aimed to evaluate the relationship of these personality traits to SUDs, and the sensitivity of SURPS in differentiating SUDs patients and healthy controls in a sample of Turkish adolescents. We hypothesized that the levels of these personality traits measured by SURPS would be found significantly higher in Turkish adolescents with SUDs compared to others.

\section{METHOD}

\section{Participants}

The approval for the design and data collection procedures was obtained from the ethics review committee of Yildirim Beyazit University, Ankara. The sample for the study was selected among outpatients referred to Ankara Child Health and Diseases Hematology Oncology Training and Research Hospital, Department of Child and Adolescent Psychiatry, and Bakirkoy Prof. Dr. Mazhar Osman Training and Research Hospital, Child and Adolescent Alcohol and Drug Research Treatment and Training Center, and communitybased healthy controls from July to September 2017. Literate and volunteered adolescents between the ages of 13 and 18 who have no sensory deficits were included in the study. Those with severe physical (orthopedic disability, cerebral palsy, and encephalopathy, etc.) and psychiatric (intellectual disability, bipolar manic episode, and psychotic episode, etc.) disorders were excluded. The sample for the first analysis consisted of 13-18year-old patients $(n=30)$ diagnosed with SUDs who abuse multiple drugs, including tobacco, alcohol, cannabis, synthetic cannabinoids, hallucinogens, stimulants, and inhalants, 13-18-year-old patients $(n=30)$ diagnosed with any psychiatric disorders other than SUDs, including major depression $(n=6)$, social phobia $(n=3)$, bipolar disorder $(n=1)$, attention deficit hyperactivity disorder $(\mathrm{n}=7)$, eating disorder $(\mathrm{n}=2)$, obsessive-compulsive disorder $(n=3)$, conversion disorder $(n=2)$, and generalized anxiety disorder $(\mathrm{n}=6)$, community-based 13-18-year-old healthy controls $(n=30)$. Mean ages in SUDs patient group, non-SUDs patient group, and non-matched healthy control group were $16.60( \pm 0.18), 15.93( \pm 0.16)$, and 16.03 
$( \pm 0.14)$, respectively. There was no statistically significant difference between the groups in terms of mean age $(\mathrm{df}=2, \mathrm{~F}=4.949, \mathrm{p}=0.009)$. The rates of male in SUDs patient group, non-SUDs patient group, and non-matched healthy control group were $93.3 \%(\mathrm{n}=28), 36.7 \%(\mathrm{n}=11)$, and $63.3 \%$ $(\mathrm{n}=19)$, respectively. There were statistically significant differences between SUDs patient group, non-SUDs patient group, and non-matched healthy control group in terms of gender distribution $\left(X^{2}\right.$ $(2)=21.045, p<0.001)$. The first analysis showed that the gender distribution was very heterogeneous between the groups, and this could affect the study results. Therefore, the analysis was repeated between the patients diagnosed with SUDs $(n=30)$ and age- and sex-matched healthy controls $(n=30)$. By psychiatric evaluations, the patient groups received the diagnoses of SUDs or any psychiatric disorders according to the DSM-IV-TR criteria.

\section{Measures}

The assessment was consisted of clinical examination and five self-administered instruments: (1) Substance Use Risk Profile Scale; (2) Beck Hopelessness Scale; (3) State-Trait Anxiety Inventory; (4) Barratt Impulsivity Scale; and (5) Arnett Inventory of Sensation Seeking.

(1) The Substance Use Risk Profile Scale (SURPS), a self-report instrument of 23-items rated on the Likert-scale (1=strongly disagree to $4=$ strongly agree), was developed to screen for the four high-risk personality traits (hopelessness, anxiety sensitivity, impulsivity, and sensation seeking) for substance abuse (11). The validation of the SURPS has been replicated in Turkey (12). A higher score on any subscale of the SURPS means a higher risk of substance use.

(2) The Beck Hopelessness Scale (BHS), a 20-item instrument rated on a "yes" or "no" response (13), has shown adequate psychometric properties in Turkish population $(14,15)$. Higher scores on BHS indicate a higher level of hopelessness.

(3) The State-Trait Anxiety Inventory (STAI) state subscale consists of 20 items describing how people feel at a particular moment in time rated on the
Likert scale (1-4 points) (16). The STAI trait subscale consists of 20 items describing how they generally feel rated on the Likert scale (1-4 points) (16). The STAI has been validated in the Turkish population (17). The score on each subscale of the STAI varies between 20-80. Higher scores mean a higher level of anxiety.

(4) The Barratt Impulsivity Scale (BIS) which comprises 30-items scored on the 4-point Likert instrument, ranging from 1 ("rarely/never") to 4 ("almost always/always"), includes three subscales labeled attentional, non-planning, and motor (18). The validation of the BIS has been replicated in Turkey (19). Higher total scores on BIS indicate higher impulsivity level.

(5) The Arnett Inventory of Sensation Seeking (AISS), composed of 20 items rated on the Likert scale (1-4 points) (20), has adequate psychometric properties in Turkish population (21). The score on the AISS varies between 19-76. A higher score indicates a higher level of sensation seeking.

\section{Statistical Analyses}

Statistical analyses were carried out using SPSS 17.0 software. P-values $\leq 0.05$ were considered statistically significant. In the first analysis, one-way ANOVA and Tukey posthoc tests were applied to compare normally distributed scores of STAI, BIS, AISS, BHS, and SURPS anxiety sensitivity, hopelessness, sensation-seeking, and impulsivity subscales among the patients diagnosed with SUDs, the patients diagnosed with any psychiatric disorders other than SUDs, and community-based healthy controls. In addition, the associations of the SURPS subscales with BHS, STAI, BIS, and AISS were determined by Pearson correlation coefficients. And then, the second analysis was performed to minimize bias because of the gender heterogeneity in the groups. Normally distributed SURPS subscale scores were compared between the patients diagnosed with SUDs and age- and sex-matched healthy controls by independent samples t-test. 


\section{RESULTS}

In the first analysis, there were no statistically significant differences between the SUDs patient group, the non-SUDs patient group, and the nonmatched healthy control group in terms of SURPS impulsivity, sensation-seeking, and anxiety sensitivity subscale scores (Table 1). SURPS hopelessness subscale scores were found to be significantly higher in the non-SUDs patient group than in the other groups (Table 1). There were significantly low-moderate correlations in the range of 0.3050.709 between the SURPS subscales and the other scales (Table 2). There were no statistically significant differences between the SUDs patient group, the non-SUDs patient group, and the non-matched healthy control group in terms of BIS and AISS (BIS total score; $\mathrm{df}=2, \mathrm{~F}=1.853, \mathrm{p}=0.163$, AISS; $\mathrm{df}=2, \mathrm{~F}=0.107, \mathrm{p}=0.899)$ (Table 1). The scores of STAI and BHS were found to be significantly higher in the non-SUDs patient group than in the other groups (STAI state subscale; $\mathrm{df}=2, \mathrm{~F}=3.997$, $\mathrm{p}=0.022$, STAI trait subscale; $\mathrm{df}=2, \mathrm{~F}=10.744$, $\mathrm{p}<0.001$, and $\mathrm{BHS} ; \mathrm{df}=2, \mathrm{~F}=8.453, \mathrm{p}<0.001$ ) (Table 1).

The analysis for comparison of the SURPS subscale scores among the SUDs patient group and another healthy control group matched for age and sex was repeated. Mean subscale scores of the SURPS hopelessness, anxiety sensitivity, impulsivity, and sensation seeking in the SUDs patient group were $12.87( \pm 0.77), 11.17( \pm 0.58), 10.67$ $( \pm 0.62)$, and $15.67( \pm 0.62)$, respectively. Also in the age- and sex-matched healthy control group, they were $13.07( \pm 0.72), 10.67( \pm 0.54), 9.70$
$( \pm 0.62)$, and $15.30( \pm 0.67)$, respectively. In the second analysis, there was no statistically significant difference between both of them in terms of SURPS hopelessness, impulsivity, sensation-seeking, and anxiety sensitivity subscale scores (SURPS hopelessness subscale; $\mathrm{t}(58)=-0.190, \mathrm{p}=0.850$, impulsivity subscale; $\mathrm{t}(58)=1.106, \mathrm{p}=0.273$, sensation-seeking subscale; $\mathrm{t}(58)=0.402, \mathrm{p}=0.689$, and anxiety sensitivity subscale $\mathrm{t}(58)=0.627, \mathrm{p}=0.533$ ).

\section{DISCUSSION}

We suggested that there was no relationship between the substance abuse-related personality traits measured with SURPS, and substance use disorders. Cross-sectional and prospective associations between the personality traits (e.g., impulsive/sensation-seeking or deficits in behavioral inhibition) and substance use disorders were demonstrated by using the Tridimensional Personality Questionnaire (TPQ) and the Eysenck Personality Questionnaire (EPQ) $(10,22)$. Also being used the NEO-Five Factor Inventory (NEOFFI), alcohol use disorders were shown to be positively or negatively related to some personality traits such as neuroticism, agreeableness, and conscientiousness (23). According to the present data, using SURPS, the cross-sectional relationship could not be replicated in a sample consisted of Turkish adolescents.

Discriminative relationships between the personality traits measured with SURPS and the drug use measures were indicated in both community-based and substance-abusing samples $(11,24)$. Each of the

Table 1: Evaluations of BIS, AISS, STAI, BHS, SURPS impulsivity, sensation-seeking, hopelessness, and anxiety sensitivity subscale scores between the groups in the first analysis.

\begin{tabular}{lllllll}
\hline & $\begin{array}{l}\text { SUDs Patient } \\
\text { Group }\end{array}$ & $\begin{array}{l}\text { Non-SUDs } \\
\text { Patient Group }\end{array}$ & $\begin{array}{l}\text { Healthy Control } \\
\text { Group }\end{array}$ & df & F & p \\
\hline SURPS Impulsivity & $10.67(-0.62)$ & $12.48(-0.70)$ & $10.76(-0.62)$ & 2 & 2.564 & 0.083 \\
\hline SURPS Sensation-Seeking & $15.67(-0.62)$ & $16.38(-0.74)$ & $16.59(-0.83)$ & 2 & 0.495 & 0.611 \\
\hline SURPS Hopelessness & $12.87(-0.77)$ & $17.90(-0.99)$ & $12.41(-0.75)$ & 2 & 13.253 & 0.000 \\
\hline SURPS Anxiety Sensitivity & $11.17(-0.58)$ & $12.24(-0.67)$ & $12.31(-0.60)$ & 2 & 0.931 & 0.398 \\
\hline BIS & $66.43(-1.98)$ & $70.00(-1.97)$ & $65.07(-1.71)$ & 2 & 1.853 & 0.163 \\
\hline AISS & $43.03(-1.27)$ & $42.41(-1.78)$ & $41.83(-1.44)$ & 2 & 0.107 & 0.899 \\
\hline STAI State Subscale & $37.63(-1.70)$ & $45.34(-2.09)$ & $38.83(-1.63)$ & 2 & 3.997 & 0.022 \\
\hline STAI Trait Subscale & $43.80(-1.36)$ & $54.03(-1.96)$ & $45.10(-1.62)$ & 2 & 10.744 & 0.000 \\
\hline BHS & $5.70(-0.61)$ & $10.03(-1.11)$ & $4.69(-0.62)$ & 2 & 8.453 & 0.000 \\
\hline SURPS: Subs
\end{tabular}

SURPS: Substance Use Risk Profile Scale, BIS: Barratt Impulsivity Scale, AISS: Arnett Inventory of Sensation Seeking, STAI: State-Trait Anxiety Inventory, BHS: Beck Hopelessness Scale, SUD: Substance Use Disorder, Oneway ANOVA,

Post Hoc Analysis (Tukey s HSD Test); $<<0.05$ 
specific personality profiles is associated with a particular substance misuse $(6,11)$. While anxiety sensitivity that is protective in early adolescence is associated with lower levels of substance use among young adolescents, the one that is a risk factor for later substance misuse is associated with high levels of drinking problems, and other drug use among adults (including alcohol use, anxiolytic/sedative use, and tobacco use) (9). Hopelessness is associated with early-onset of alcohol use, risk for alcohol dependence, and susceptibility to opiate use/misuse in adulthood (6). Impulsivity and sensation seeking are also linked to elevated substance use patterns (including poly-substance use, stimulant use/misuse, and drinking problem). Newton et al. found the four personality traits were consistent with specific substance use either concurrently or prospectively, but that hopelessness was not associated with illicit drug use in the Australian sample (25). Castellanos-Ryan et al. reported that prospectively evaluating with SURPS, impulsivity was the most consistent and strongest predictor of substance use, hopelessness was a general vulnerability factor for most problems including substance use, sensation seeking was associated with early onset drinking and general drug use, and anxiety sensitivity was associated with reduced substance use outcomes in young adolescence (26). Also, like the present study, Siu found no significant difference between each personality trait and substance use in Chinese adolescents (27).

The sensitivity of SURPS in differentiating SUDs patients and healthy controls in a sample consisted of Turkish adolescents was not supported in the present study. One possible explanation of the fact is that adolescents with SUDs could not report their feelings, experiences, and patterns of personality correctly themselves due to their neurocognitive functions (including working memory, selective attention, cognitive control, executive functions, learning, and memory) impaired by neurophysiopathological effects of chronic polysubstance misuse (28). Another reason why the personality traits in adolescents with substance use disorders were not found as expected, could be related to multiple substance abuse of all SUDs patients in the sample. Finally, one reason could also be the failure to evaluate the insight and treatment motivations of SUDs patients (29).

In the present study, it was found that the mean scores of BIS, AISS, STAI, BHS, and the SURPS subscales in SUDs patients were not significantly different from the ones in the other groups. Uygun et al. reported similar scores of the scales in a community based large sample consisted of Turkish adolescents (12). These results may be related to this feature of the SURPS subscales that measure the risk of future substance use, especially before substance use disorder develops. Not surprisingly, the mean scores of BHS, STAI, and SURPS hopelessness in the patients diagnosed with any psychiatric disorders other than SUDs (including major depression, social phobia, bipolar disorder, attention deficit hyperactivity disorder, eating disorder, obsessive-compulsive disorder, conversion disorder, and generalized anxiety disorder) were found to be significantly higher than the ones in the other groups. The statement "hopelessness" can be related to negative core beliefs about selves, other people, the world, and future in the patients with these disorders (30).

The results of this study should be considered in the light of several limitations. First, substance use profiles and motives for substance use could not be evaluated in the present study. SURPS appraises the risk of particular substance use rather than directly diagnosis of SUDs by assessing these motives through the personality dimensions.

Table 2. Correlations between the SURPS subscales and the other scales in the first analysis.

\begin{tabular}{|c|c|c|c|c|}
\hline \multirow{2}{*}{$\begin{array}{l}\text { Pearson Correlation } \\
\text { Coefficient }\end{array}$} & \multicolumn{4}{|l|}{ SURPS } \\
\hline & Hopelessness & Impulsivity & Sensation Seeking & Anxiety Sensitivity \\
\hline BHS & $0.709 * *$ & & & \\
\hline BIS & & $0.566 * *$ & & \\
\hline AISS & & & $-0.594 * *$ & \\
\hline STAI State Subscale & & & & $0.305 * *$ \\
\hline STAI Trait Subscale & & & & $0.418 * *$ \\
\hline
\end{tabular}


Further studies evaluating the relationship between the four personality traits and specific substance use profiles in Turkish samples are necessary either concurrently or prospectively. Second, the design of the present study was cross-sectional. Longitudinal studies are needed to address the causal relationship between the personality traits and subsequent development of substance abuse. Third, the data were collected through self-reports that can be problematic. Nevertheless, given assurance of confidentiality, assessing substance use directly seems to be a reasonable approach. Fourth, the sample size (both the SUDs patient group and the healthy control group matched for age and sex) was small. The results can not necessarily be generalized. Fifth, the prevalence of psychiatric comorbidity and the distribution of other psychiatric diagnoses in the patients with substance use disorders could not be evaluated. It is known that there is a bidirectional relationship between substance use disorders and psychiatric comorbidities. Finally, the sociodemographic variables such as levels of socioeconomic status, mother and father education, which are important risk factors in the etiology of substance use disorders, could not be questioned in the study. The absence of these variables may interfere with the interpretation of the results appropriately. Therefore, further studies evaluating psychiatric comorbidities, and the sociodemographic confounders related to substance use disorders as well are needed.

\section{CONCLUSION}

Despite these limitations, our study is the first study assessing the sensitivity of SURPS in differentiating SUDs patients and healthy controls in a sample consisted of Turkish adolescents. Further studies are needed for examining the relationship between substance abuse-related personality dimensions measured with SURPS, and specific patterns of substance use in large population-based samples, rather than in randomized groups according to diagnosis of SUDs.

Correspondence address: M. D. Sabide Duygu Uygun, University of Health Sciences, Dr. Sami Ulus Maternity, Children's Health and Diseases Training and Research Hospital, Department of Child and Adolescent Psychiatry, Ankara, Turkey st.duygu@hotmail.com

\section{REFERENCES}

1. Barclay RP, Hilt RJ. Integrated Care for Pediatric Substance Abuse. Child Adolesc Psychiatr Clin N Am. 2016;25:769-77.

2. Peiper NC, Ridenour TA, Hochwalt B, Coyne-Beasley T. Overview on Prevalence and Recent Trends in Adolescent Substance Use and Abuse. Child Adolesc Psychiatr Clin N Am. 2016;25:349-65.

3. Borus J, Parhami I, Levy S. Screening, Brief Intervention, and Referral to Treatment. Child Adolesc Psychiatr Clin N Am. 2016;25:579-601.

4. LeNoue SR, Riggs PD. Substance Abuse Prevention. Child Adolesc Psychiatr Clin N Am. 2016;25:297-305.

5. Comeau N, Stewart SH, Loba P. The relations of trait anxiety, anxiety sensitivity, and sensation seeking to adolescents' motivations for alcohol, cigarette, and marijuana use. Addictive Behaviors. 2001;26:803-25.

6. Conrod P, Woicik P. Validation of a four-factor model of personality risk for substance abuse and examination of a brief instrument for assessing personality risk. Addict Biol. 2002;7:329-46

7. Castellanos-Ryan N, Conrod PJ. Personality correlates of the common and unique variance across conduct disorder and substance misuse symptoms in adolescence. Journal of abnormal child psychology. 2011;39:563-76.
8. Conrod PJ, Pihl RO, Stewart SH, Dongier M. Validation of a system of classifying female substance abusers on the basis of personality and motivational risk factors for substance abuse. Psychology of Addictive Behaviors. 2000;14:243-56.

9. Krank M, Stewart SH, O'Connor R, Woicik PB, Wall AM, Conrod PJ. Structural, concurrent, and predictive validity of the Substance Use Risk Profile Scale in early adolescence. Addict Behav. 2011;36:37-46.

10. Sher KJ, Bartholow BD, Wood MD. Personality and substance use disorders: a prospective study. Journal of consulting and clinical psychology. 2000;68:818.

11. Woicik PA, Stewart SH, Pihl RO, Conrod PJ. The Substance Use Risk Profile Scale: a scale measuring traits linked to reinforcement-specific substance use profiles. Addict Behav. 2009;34:1042-55.

12. Uygun SD, Cop E, Uneri OS, Ozdel K, Atar E, Munir KM. Psychometric evaluation of the Turkish version of the Substance Use Risk Profile Scale in adolescents. Journal of ethnicity in substance abuse. 2019:1-16.

13. Beck AT, Weissman A, Lester D, Trexler L. The measurement of pessimism: the hopelessness scale. Journal of consulting and clinical psychology. 1974;42:861.

14. Seber G, Dilbaz N, Kaptanoğlu C, Tekin D. Umutsuzluk ölçeği: Geçerlilik ve güvenirliği. Kriz Dergisi. 1993;1:139-42. 
15. Durak A, Palabıyıkoğlu R. Beck Umutsuzluk Ölçeği Geçerlilik Çalışması. Kriz Dergisi. 1994;2:311-9.

16. Spielberger CD, Gorsuch RL, Lushene RE. Manual for the state-trait anxiety inventory. 1970.

17. Oner N, Le Compte A. Durumluk-Surekli kaygi envanteri el kitabi. Istanbul: Boğaziçi Yayinları. 1985.

18. Patton JH, Stanford MS. Factor structure of the Barratt impulsiveness scale. Journal of clinical psychology. 1995;51:76874.

19. Güleç H, Tamam L, Güleç MY, Turhan M, Karakuş G, Zengin M, et al. Psychometric properties of the Turkish version of the Barratt Impulsiveness Scale-11. Klinik Psikofarmakoloji Bülteni. 2008;18:251-8.

20. Arnett J. Sensation seeking: A new conceptualization and a new scale. Personality and individual differences. 1994;16:28996.

21. Sümer N. Personality and behavioral predictors of traffic accidents: testing a contextual mediated model. Accident Analysis \& Prevention. 2003;35:949-64.

22. Jackson KM, Sher KJ. Alcohol use disorders and psychological distress: a prospective state-trait analysis. Journal of abnormal psychology. 2003;112:599.

23. Martin ED, Sher KJ. Family history of alcoholism, alcohol use disorders and the five-factor model of personality. Journal of Studies on Alcohol. 1994;55:81-90.

24. Schlauch RC, Crane CA, Houston RJ, Molnar DS, Schlienz NJ, Lang AR. Psychometric Evaluation of the Substance Use Risk Profile Scale (SURPS) in an Inpatient Sample of Substance Users Using Cue-Reactivity Methodology. J Psychopathol Behav Assess. 2015;37:231-46.

25. Newton NC, Barrett EL, Castellanos-Ryan N, Kelly E, Champion KE, Stapinski L, et al. The validity of the Substance Use Risk Profile Scale (SURPS) among Australian adolescents. Addict Behav. 2016;53:23-30.

26. Castellanos-Ryan N, O'Leary-Barrett M, Sully L, Conrod P. Sensitivity and specificity of a brief personality screening instrument in predicting future substance use, emotional, and behavioral problems: 18 -month predictive validity of the Substance Use Risk Profile Scale. Alcohol Clin Exp Res. 2013;37 Suppl 1:E281-90

27. Siu AF. Validation of the substance use risk profile scale for adolescents in Hong Kong. Journal of Psychoeducational Assessment. 2011;29:75-83.

28. Hagen E, Sømhovd M, Hesse M, Arnevik EA, Erga AH. Measuring cognitive impairment in young adults with polysubstance use disorder with MoCA or BRIEF-A-The significance of psychiatric symptoms. Journal of substance abuse treatment. 2019;97:21-7.

29. Gressler L, Natafgi N, DeForge B, Shaneman-Robinson B, Welsh C, Shaya F. What motivates people with substance use disorders to pursue treatment? A patient-centered approach to understanding patient experiences and patient-provider interactions. Journal of Substance Use. 2019:1-13.

30. Overholser JC. From puddles to potholes: the role of overvalued beliefs in emotional problems. Journal of Contemporary
Psychotherapy. 2018;48:41-50. 